\title{
A new and efficient protocol for preparation of thiol esters from carboxylic acids and thiols in the presence of 2-(1H-benzotriazole-1-yl)-1,1,3,3-tetramethyluronium tetrafluoroborate (TBTU)
}

\author{
Barahman Movassagh, ${ }^{a, b *}$ Saeed Balalaie, ${ }^{a *}$ and Pershang Shaygan ${ }^{a}$ \\ ${ }^{a}$ Department of Chemistry, K. N. Toosi University of Technology, P.O. Box 16315-1618 \\ Tehran-Iran \\ ${ }^{\mathrm{b}}$ Kermanshah Oil Refning Company, Kermanshah, Iran \\ E-mail:bmovass1178@yahoo.com,balalaie@kntu.ac.ir
}

\begin{abstract}
A novel and convenient method has been developed for the synthesis of thiol esters from the corresponding carboxylic acids and thiols at room temperature using 2-(1H-benzotriazole-1-yl)1,1,3,3-tetramethyluronium tetrafluoroborate (TBTU) as the coupling reagent.
\end{abstract}

Keywords: Thiol esters, TBTU, coupling reagent, carboxylic acids, thiols

\section{Introduction}

Thiol esters show higher reactivity and selectivity toward nucleophiles than their oxygen analogues. They play important roles in biological systems such as acyl coenzyme A, and Sacetyl dihydrolipolic acid. ${ }^{1}$ Thiol esters are used as mild acyl transfer reagents, ${ }^{2}$ as intermediates in the synthesis of ketones $^{3}$, for asymmetric aldol reactions ${ }^{4}$ and in the preparation of macrocyclic lactones. ${ }^{5}$ The growing importance of thiol esters in organic synthesis has stimulated recent extensive research towards improved methods for their preparation. ${ }^{6}$ Thiol esters are generally prepared from compounds having an active carbonyl group such as acid chlorides ${ }^{6 \mathrm{j}, 61-\mathrm{n}}$ or carboxylic acid anhydrides. ${ }^{6 \mathrm{k}}$ We have recently reported the synthesis of thiol esters from $\mathrm{N}$ acylphthalimides and thiols in the presence of $\mathrm{KF} / \mathrm{Al}_{2} \mathrm{O}_{3}{ }^{7}$ Recently, Katritzky and coworkers introduced a procedure for preparation of thiol esters by reactions of $\mathrm{N}$-acylbenzotriazoles with thiols. ${ }^{8}$

Coupling of carboxylic acids with a variety of nucleophiles to prepare amides, esters, thiol esters, etc. continues to be one of the most commonly used transformations in organic chemistry. ${ }^{1}$ Modern coupling reagents utilize an equimolar amount of acid and nucleophile. 
Besides being effective and easily handled, it is crucial that the conditions employed are mild and compatible with a wide variety of functional groups including the most commonly protecting groups. $^{9,10}$

Coupling reactions of carboxylic acids with thiols using carbodiimides such as DCC and EDC \{1-[3-(dimethylamino)propyl]-3-ethylcarbodiimide hydrochloride $\}$ are common methods for synthesis of thiol esters. ${ }^{11}$ Although the procedure gives the products in good yields, ${ }^{11}$ equimolar amounts of highly insoluble ureas are formed which can cause difficulties in purification of the main product. A recent $\operatorname{method}^{12}$ using tetramethylfluoroformamidinium hexafluorophosphate (TFFH) as the coupling reagent for the reaction of carboxylic acids with thiols gave the corresponding thiol esters in 60-94\% yields.

The coupling reagent field has clearly evolved in the last decade from carbodiimides to onium (phosphonium and uronium) salts. One of such onium salts is 2-(1-H-benzotriazole-1-yl)1,1,3,3-tetramethyluronium tetrafluoroborate (TBTU) which has been used as an activating agent of carboxylic acids for preparation of 1,2,4, oxadiazoles, ${ }^{13}$ amides and phenylhydrazides, ${ }^{14}$ and esters. $^{15}$

\section{Results and Discussion}

Here we wish to report our results demonstrating the use of TBTU as a coupling reagent in the reaction of carboxylic acids with thiols for the synthesis of thiol esters (Scheme 1).

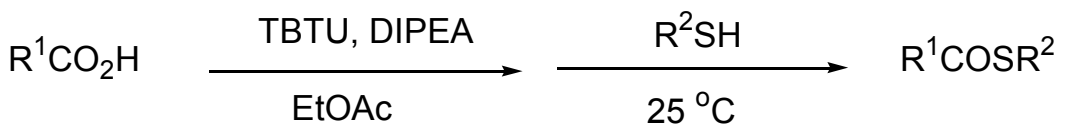

\section{Scheme 1}

The results are summarised in Table 1. The reaction can be performed with aromatic and aliphatic carboxylic acids and thiols at room temperature. The yields of thiol esters are in the range $72-92 \%$. The structures of all the products were established from their analytical and spectral (IR, ${ }^{1} \mathrm{H}$ and ${ }^{13} \mathrm{C} \mathrm{NMR}$ ) properties. The reactions between various carboxylic acids and aromatic thiols are in general very fast and complete in 15-45 min. The results show clearly the need for much longer reaction times for aliphatic thiols (benzyl mercaptan, entries 5 and 7, Table 1). The effects of several solvents were examined and the best results were obtained with ethyl acetate (EtOAc).

The proposed mechanism for this coupling reaction is depicted (Scheme 2). X-Ray crystallographic studies have revealed that TBTU exists, at least in the solid state, as zwitterion 1 comprising a triazol-N-oxide and a guanidinium moiety. ${ }^{16} N, N^{\prime}$-Diisopropylethylamine (DIPEA) 
removes the acidic hydrogen from the carboxylic acid, and the carboxylate anion reacts with TBTU. The intermediate acyloxy-aminium/uronium salt 2 cannot be detected and reacts immediately with the benzotriazole derivative to give $\mathbf{3}$, which reacts with thiol to give the corresponding thiol ester $\mathbf{4}$ and 1-hydroxybenzotriazole (HOBt, 5) as a water-soluble by-product.

\section{Conclusions}

In summary, TBTU has been introduced as an efficient $S$-acylating reagent of thiols to give diverse thiol esters in high to excellent yields. The present method has the advantages of operational simplicity, mild reaction conditions, ready availability and use of non-toxic materials, fast reaction rates, and simple reaction work-up.

Table 1. Thiol esters from carboxylic acids and thiols using TBTU

\begin{tabular}{|c|c|c|c|c|}
\hline Entry & $\mathrm{R}^{1}$ & $\mathrm{R}^{2}$ & $\begin{array}{l}\text { Time } \\
(\min )\end{array}$ & $\begin{array}{l}\text { Thiol ester } \\
\text { Yields }(\%)^{\mathrm{a}, \mathrm{t}}\end{array}$ \\
\hline 1 & $\mathrm{Ph}$ & $\mathrm{Ph}$ & 30 & $86^{16}$ \\
\hline 2 & $\mathrm{Ph}$ & $4-\mathrm{MeC}_{6} \mathrm{H}_{4}$ & 30 & $82^{16}$ \\
\hline 3 & $\mathrm{Ph}$ & $4-\mathrm{MeOC}_{6} \mathrm{H}_{4}$ & 45 & $72^{16}$ \\
\hline 4 & $\mathrm{Ph}$ & $4-\mathrm{ClC}_{6} \mathrm{H}_{4}$ & 15 & $91^{6 \mathrm{k}}$ \\
\hline 5 & $\mathrm{Ph}$ & $\mathrm{PhCH}_{2}$ & 150 & $78^{17}$ \\
\hline 6 & $\mathrm{PhCH}_{2}$ & $\mathrm{Ph}$ & 30 & $74^{18}$ \\
\hline 7 & $\mathrm{PhCH}_{2}$ & $\mathrm{PhCH}_{2}$ & 360 & $92^{6 f}$ \\
\hline 8 & $4-\mathrm{ClC}_{6} \mathrm{H}_{4}$ & $\mathrm{Ph}$ & 20 & $92^{19}$ \\
\hline 9 & $n-\mathrm{C}_{11} \mathrm{H}_{23}$ & $\mathrm{Ph}$ & 15 & $77^{17}$ \\
\hline 10 & $n-\mathrm{C}_{15} \mathrm{H}_{31}$ & $\mathrm{Ph}$ & 15 & $84^{6 \mathrm{i}}$ \\
\hline
\end{tabular}

${ }^{\mathrm{a}}$ Yields refer to those of pure isolated products characterized by IR, ${ }^{1} \mathrm{H}$ and ${ }^{13} \mathrm{C}$ NMR spectroscopy ${ }^{\mathrm{b}}$ references for known compounds. 


\section{Experimental Section}

General Procedures. TBTU was purchased from Zhejiang company (China). All products were characterized by comparison of their spectroscopic data with those of known samples. IR spectra were obtained using an ABB FTLA 2000 instrument. NMR spectra were recorded on a Bruker AQS 300 Avance instrument at $300 \mathrm{MHz}$ for ${ }^{1} \mathrm{H}$ and at $75 \mathrm{MHz}$ for ${ }^{13} \mathrm{C} \mathrm{NMR}$ in $\mathrm{CDCl}_{3}$ solutions.

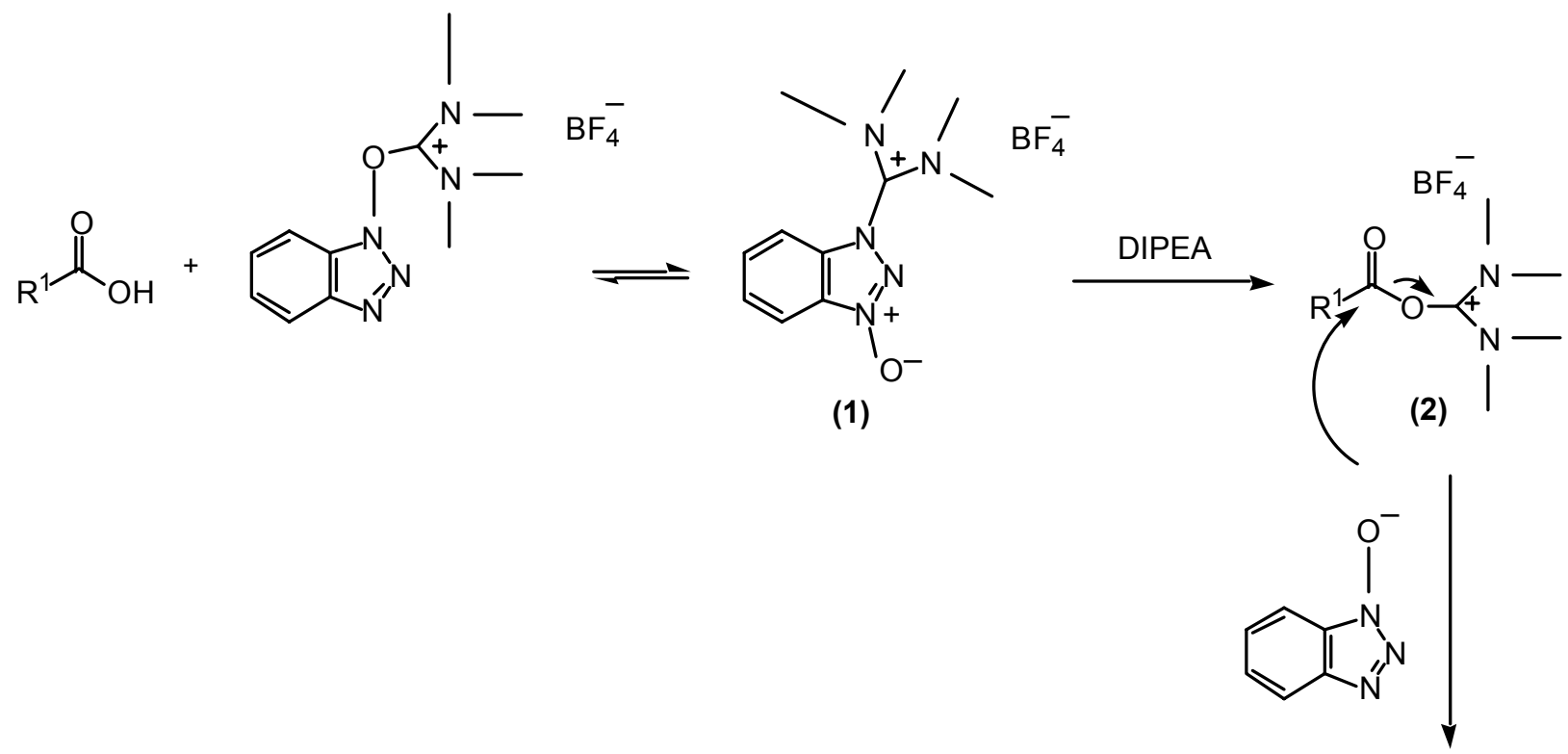<smiles>[R]SC([R])=O</smiles>

(5)
(4)

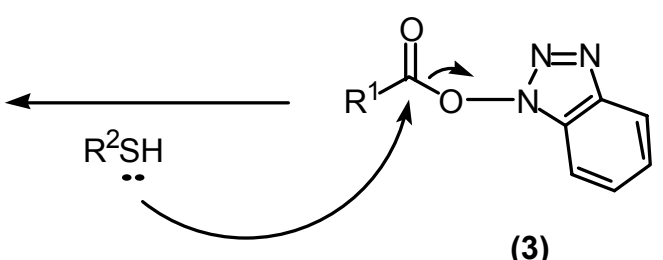

(3)

\section{Representative experimental procedure for preparation of $S$-(4-methylphenyl) benzenecarbothioate (entry 2 , Table 1)}

To a solution of benzoic acid $(122 \mathrm{mg}, 1.0 \mathrm{mmol})$ dissolved in EtOAc $(35 \mathrm{~mL})$ were added TBTU (353 mg, $1.1 \mathrm{mmol})$ and DIPEA (198 mg, $1.5 \mathrm{mmol})$ and the mixture was stirred at $25^{\circ} \mathrm{C}$. After $30 \mathrm{~min}$, 4-methylthiophenol (124mg, $1.0 \mathrm{mmol}$ ) was added and the reaction was allowed to proceed for $30 \mathrm{~min}$. The solvent was evaporated in vacuo to give the crude product, which was purified by preparative thin layer chromatography (silica gel, eluent EtOAc/ $n$-heptane $=1: 3$ ) to afford the pure thiol ester $(187 \mathrm{mg}, 82 \%)$ as colorless crystals, $\mathrm{mp} 64.2-65.1{ }^{\circ} \mathrm{C}$ (lit. ${ }^{17} \mathrm{mp} 65-$ $\left.66{ }^{\circ} \mathrm{C}\right)$; IR (KBr) $v 1674 \mathrm{~cm}^{-1} ;{ }^{1} \mathrm{H}$ NMR $\delta 2.43(\mathrm{~s}, 3 \mathrm{H}), 7.30(\mathrm{~d}, J=8.1 \mathrm{~Hz}, 2 \mathrm{H}), 7.42(\mathrm{~d}, J=8.1$ $\mathrm{Hz}, 2 \mathrm{H}), 7.50(\mathrm{t}, J=7.6 \mathrm{~Hz}, 2 \mathrm{H}), 7.63(\mathrm{t}, J=7.4 \mathrm{~Hz}, 1 \mathrm{H}), 8.05(\mathrm{~d}, J=8.5 \mathrm{~Hz}, 2 \mathrm{H}) ;{ }^{13} \mathrm{C}$ NMR $\delta$ $21.38,123.75,127.46,128.71,130.10,133.56,135.02,136.70,139.80,190.59$. 


\section{Selected physical and spectral data}

$\boldsymbol{S}$-Benzyl phenylethanethioate (entry 7). ${ }^{\mathbf{6}}$ Oil; IR (neat) $v 1689,1504,1458 \mathrm{~cm}^{-1} ;{ }^{1} \mathrm{H}$ NMR $\delta$ $3.87(\mathrm{~s}, 2 \mathrm{H}), 4.14(\mathrm{~s}, 2 \mathrm{H}), 7.25-7.39(\mathrm{~m}, 10 \mathrm{H}) ;{ }^{13} \mathrm{C}$ NMR $\delta 33.62,50.23,127.28,127.46,128.61$, $128.67,128.86,129.62,133.44,137.27,196.80$.

$\boldsymbol{S}$-Phenyl $\boldsymbol{n}$-dodecanethioate (entry 9). ${ }^{\mathbf{1 8}}$ Oil; IR (neat) $v 1702 \mathrm{~cm}^{-1} ;{ }^{1} \mathrm{H}$ NMR $\delta 0.90$ (t, $J=6.9$ $\mathrm{Hz}, 3 \mathrm{H}$ ), 1.25-1.29 (m, 16H), 1.73 (quin, $J=7.5 \mathrm{~Hz}, 2 \mathrm{H}), 2.67$ (t, $J=7.4 \mathrm{~Hz}, 2 \mathrm{H}), 7.43$ (s, 5H); ${ }^{13} \mathrm{C}$ NMR $\delta 14.10,22.67,25.59,28.94,29.23,29.31,29.40,29.57,31.89,43.72,127.95,129.12$, $129.25,134.46,197.59$.

\section{Acknowledgements}

Support of this research by a grant from the K. N. Toosi University of Technology Research Council and Kermanshah Oil Refining Company is gratefully acknowledged.

\section{References}

1. (a) Bruice, T. C. In Organic Sulfur Compounds; Kharasch, N., Ed.; Pergamon Press: New York and London, 1961; Vol. 1, Chap. 35. (b) Bruice, T. C.; Benkovic, S. J. Bioorganic Mechanism; Benjamin Inc.: New York and Amsterdam, 1966; Vol. 1, Chap. 3,

2. Mukaiyama, J.; Araki, M.; Takei, H. J. Am. Chem. Soc. 1973, 95, 4763.

3. (a) Conrow, R.; Portoghese, P. J. Org .Chem. 1986, 51, 938. (b) McGarvey, G. J.; Williams, J. M.; Hiner, R. N.; Matsubara, Y.; Oh, T. J. Am. Chem. Soc. 1986, 108, 4943.

4. (a) Suh, K. K.; Choo, D. J. Tetrahedron Lett. 1995, 36, 6109. (b) Kobayashi, S.; Uchiro, H.; Fujishita, Y.; Shiina, I.; Mukaiyama, T. J. Am. Chem. Soc. 1991, 113, 4247.

5. Buch, T. J. Tetrahedron 1977, 33, 3041.

6. (a) Gauthier, J. Y.; Bourdon, F.; Young, N. Tetrahedron Lett. 1986, 27, 15. (b) Giovanni, P.; Marino, N.; Giacomo, G.; Marcos, F. Tetrahedron 1989, 45, 7411. (c) Ramon, B.; Jordi, G.; Jaume, V. Synthesis 1989, 305. (d) Cardellicchio, C.; Fiandanese, V.; Marchese, G.; Ronzini, L. Tetrahedron Lett. 1985, 26, 3595. (e) Saeed, A.; Javed, I. Tetrahedron Lett. 1986, 27, 3791. (f) Hatch, R. P.; Weinreb, S. M. J. Org. Chem. 1977, 42, 3960. (g) Sucheta, K.; Reddy, G. S.; Ravi, D.; Rao, N. R. Tetrahedron Lett. 1994, 35, 4415. (h) Braga, A. L.; Rodrigues, O. E. D.; Avila, E. D.; Silveira, C. C. Tetrahedron Lett. 1998, 39, 3395. (i) Liu, H.-J. Sabesan, S. I. Can. J. Chem. 1980, 58, 2645. (j) Meshram, H. M.; Reddy, G. S.; Bindu, K. H.; Yadav, J. S. Synlett 1998, 877. (k) Movassagh, B.; Lakouraj, M. M.; Fadaei, Z. J. Chem. Res. (S) 2001, 22. (1) Lakouraj, M. M.; Movassagh, B.; Fadaei, Z. Monatsh. Chem. 2002, 133, 1085. (m) Mukaiyama, T.; Miyashita, M.; Shiina, I. Chem. Lett. 1992, 1747. (n) Takido, T.; Sato, K.; Nakazawa, T.; Seno, M. Sulfur Lett. 1995, 19, 67.

7. Movassagh, B.; Zakinezhad, Y. J. Chem. Res. 2006, 369. 
8. Katritzky, A. R.; Shestopalov, A. A.; Suzuki, K. Synthesis 2004, 1806.

9. (a) March, J. Advanced Organic Chemistry; Wiely Interscience: New York, 1992; pp. 904905. (b) Han, S. -Y.; Kim, Y.-A. Tetrahedron 2004, 60, 2447. (c) Alberichio, F.; Chinchilla, R.; Dodsworth, D. J.; Najera, C. Org. Prep. Proceed. Int. 2001, 33, 203.

10. Green, T. W.; Wuts, P. G. M. Protective Groups in Organic Synthesis; Wiley: New York, 1999.

11. (a) Ozaki, S.; Yoshinaga, H.; Matsui, E.; Adachi, M. J. Org. Chem. 2001, 66, 2503. (b) Ouihia, A.; René, L.; Guilhem, J.; Pascard, C.; Badet, B. J. Org. Chem. 1993, 58, 1641. (c) Hondal, R. J.; Nilsson, B. L.; Raines, R. T. J. Am. Chem. Soc. 2001, 123, 5140. (d) Jew, S.; Park, B. B.; Lim, D.; Kim, M. G.; Chung, I. K.; Kim, J. H.; Hong, C. I.; Kim, J.-K.; Park, H.- J.; Lee, J.-H.; Park, H. Bioorg. Med. Chem. Lett. 2003, 13, 609.

12. Pittelkow, M.; Kamounah, F. S.; Boas, U.; Pedersen, B.; Christensen, J. B. Synthesis 2004, 2485.

13. Poulain, R. F.; Tartar, A. L.; Déprez, B. P. Tetrahedron Lett. 2001, 42, 1495.

14. Balalaie, S.; Mehdidoust, M.; Eshaghi-Najafabadi, R. Submitted for Publication.

15. Balalaie, S.; Mehdidoust, M.; Eshaghi-Najafabadi, R. Submitted for Publication.

16. Sewald, N.; Jakubke, H.-D. Peptides: Chemistry and Biology; Wiley-VCH: Weinheim, 2002; p 202.

17. You, J. Z.; Chen, Z. C. Synthesis 1992, 521.

18. Vedejs, E.; Meier, G. P.; Powell, D. W.; Mastalerz, H. J. Org. Chem. 1981, 46, 5253.

19. Ravi, D.; Rao, N. R.; Reddy, G. S. R.; Sucheta, K.; Rao, V. J. Synlett 1994, 856.

20. Ikeda, H.; Hiraishi, S. JP 61,233,581, 1986; C. A. 1987, 106, 224523. 